DIW BERLIN

Discussion

Papers

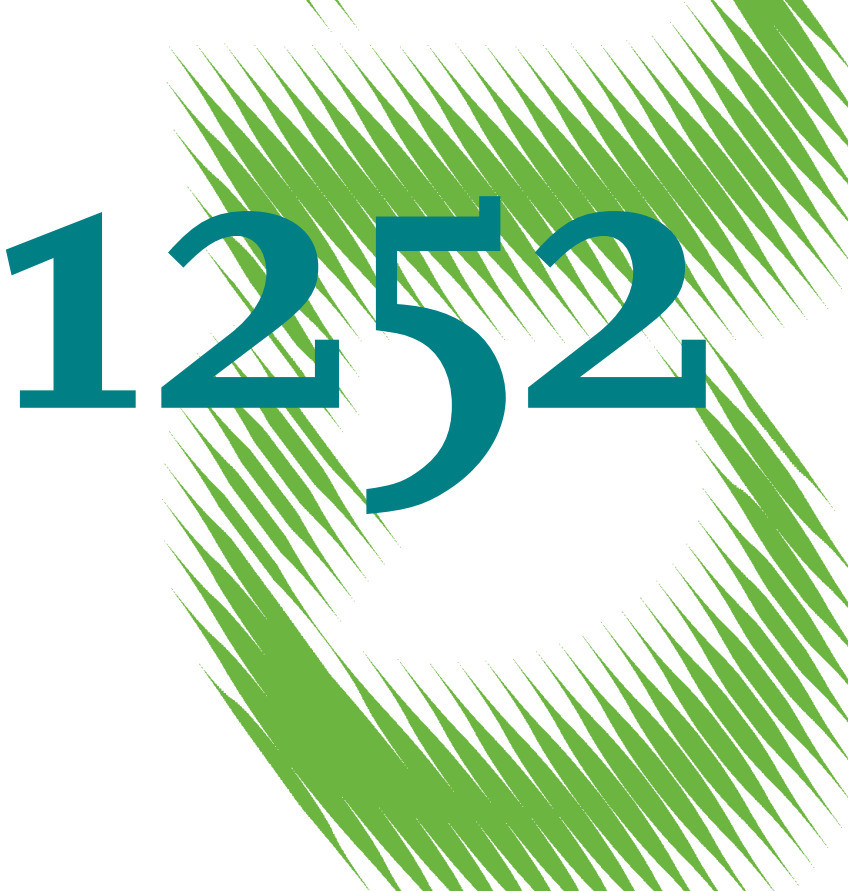

Are Uzbeks Better off than Kyrgyz?

Measuring and Decomposing Horizontal Inequality 
Opinions expressed in this paper are those of the author(s) and do not necessarily reflect views of the institute.

IMPRESSUM

(C) DIW Berlin, 2012

DIW Berlin

German Institute for Economic Research

Mohrenstr. 58

10117 Berlin

Tel. $+49(30) 89789-0$

Fax +49 (30) $89789-200$

http://www.diw.de

ISSN print edition $1433-0210$

ISSN electronic edition 1619-4535

Papers can be downloaded free of charge from the DIW Berlin website:

http://www.diw.de/discussionpapers

Discussion Papers of DIW Berlin are indexed in RePEc and SSRN:

http://ideas.repec.org/s/diw/diwwpp.html

http://www.ssrn.com/link/DIW-Berlin-German-Inst-Econ-Res.html 


\title{
Are Uzbeks Better off than Kyrgyz? Measuring and Decomposing Horizontal Inequality
}

\author{
Damir Esenaliev and Susan Steiner
}

\begin{abstract}
:
We investigate horizontal inequality between two conflictive ethnic groups, the Kyrgyz and the Uzbeks in Kyrgyzstan, by employing the Oaxaca-Blinder decomposition. This technique has a long tradition in labour economics but has not been used in the literature that links ethnic inequality and violent conflict. We measure welfare differentials between Kyrgyz and Uzbeks and find that, depending on the welfare indicator used, Uzbeks are either better off or worse off than Kyrgyz. Specifically, we find that Uzbeks are not better off, if welfare is measured in terms of household expenditure. They are, however, clearly more prosperous in terms of the value and the size of their houses - at least in urban areas, where most Uzbeks reside. The picture is mixed when we use ownership of assets as a welfare measure. We conclude that the choice of welfare indicator is essential in studies of horizontal inequality, as it is most likely the more visible aspects of life that drive people's perceptions about other ethnic groups' standard of living. Decomposing welfare differentials between Kyrgyz and Uzbeks shows that the gap in expenditure is due to differences in group characteristics, such as household composition and ownership of livestock, whereas the gap in assets and house values remains unexplained.
\end{abstract}

Keywords: Measurement of welfare, horizontal inequality, ethnic conflict, Oaxaca-Blinder decomposition, Kyrgyzstan

JEL: D74, J15, I31

Acknowledgement: We thank Tilman Brück, Olaf de Groot, Kati Schindler, Marc Vothknecht and participants of the Berlin Leibniz Seminar on Labor Research, the 2011 meeting of the Verein für Socialpolitik Research Committee on Development Economics, the Fourth Inter-University Doctoral Workshop in Development Economics, the HiCN Workshop in Barcelona, and the $12^{\text {th }}$ Jan Tinbergen European Peace Science Conference for helpful comments on earlier drafts of this paper. We are grateful to the National Statistical Committee of the Kyrgyz Republic for providing us the data of the Kyrgyz Integrated Household Survey.

Damir Esenaliev is a student in the Graduate Center at the German Institute for Economic Research (DIW Berlin). Susan Steiner is a Research Fellow at DIW Berlin.

Contact author: Susan Steiner, email: ssteiner@diw.de, Tel: +49-(0)30-89789477. 



\section{Introduction}

Much of the literature on violent conflict has recently focused on horizontal inequalities, which are "inequalities in economic, social or political dimensions or cultural status between culturally defined groups” (Stewart, 2008: 3). ${ }^{1}$ It is argued that horizontal inequalities enhance grievances and group cohesion among the relatively deprived and thus facilitate mobilisation for violent conflict (Gurr, 2000, Stewart, 2008). It is recognised that it is not only resentment by the deprived that causes political instability. The relatively privileged can also attack the unprivileged, fearing that they may demand more resources and political power (Stewart, 2008). Quantitative research has generally confirmed a positive relationship between horizontal inequality and the onset of violent conflict, both for sub-national regions within countries and for cross-country comparisons (for example, Mancini, 2008, Murshed and Gates, 2005, Østby, 2008a, Østby, 2008b).

While several indicators have been proposed to measure horizontal inequalities (Mancini, et al., 2008), very little research intends to quantitatively analyze the sources of such inequalities. The Oaxaca-Blinder decomposition (Blinder, 1973, Oaxaca, 1973) is an appropriate technique to do so. It was originally applied in labour economics to explain wage gaps between groups, such as between women and men, or between blacks and whites. The decomposition determines how much of the wage gap can be attributed to differences in group characteristics and how much is due to differences in the coefficients, sometimes interpreted as discrimination. This technique is increasingly used to examine differences in living standards (in terms of either income or household expenditure) between ethnic groups in developing countries (Baulch, et al., 2007, Baulch, et al., 2012, Bhaumik, et al., 2006, Gang, et al., 2008, Gradín, 2009, Gustafsson and Shi, 2003, Imai, et al., 2011, Kijima, 2006, van de Walle and Gunewardena, 2001). None of these studies, however, discuss the relevance of inequality between ethnic groups for the outbreak of violent conflict. Bhaumik et al. (2006), analysing the difference in per capita expenditure between Serbs and Albanians in Kosovo, is an exception. As they argue, it is imperative in a post-conflict situation that all ethnic groups feel having equal opportunities in economic and political terms. Hence, knowing more about the sources of inequality between ethnic groups may help policy-makers formulate the relevant policies in order to avoid further ethnic frictions.

In this paper, we measure welfare differentials between two potentially conflictive ethnic groups, the Kyrgyz and the Uzbeks in Kyrgyzstan, and explain these welfare

\footnotetext{
${ }^{1}$ Very similar is the concept of relative deprivation, which states that comparing oneself with those who do better may result in violence (Gurr 1970).
} 
differentials by applying an Oaxaca-Blinder decomposition. In contrast to the mentioned studies on ethnic inequality, however, we do not only rely on standard welfare measures, such as household expenditure, but we discuss alternative measures as well. Expenditure (as well as income) may not be the most relevant indicator because it is not easily observable. We propose, instead, two more visible welfare measures, i.e. the ownership of assets and the value of the house, which are more likely to provoke envy and grievances among the relatively poorer group. This builds on Stewart (2008), who notes that it is not necessarily statistically measured inequality that drives people's action, but, rather, perceived inequality. We argue that such perception may be triggered by differences in some visible aspect of life and may then be assumed to hold for overall well-being.

We study the case of Kyrgyz and Uzbeks in Kyrgyzstan because violent clashes between these two ethnic groups in June 2010 left around 470 people dead. Uzbeks, who are today the second largest ethnic group in Kyrgyzstan after the Kyrgyz, are considered to be economically more prosperous than Kyrgyz, while being politically under-represented and discriminated against (Fumagalli, 2007b, Matveeva, 2010). Both academics and media reporting on the violence largely referred to the economic disparity between Uzbeks and Kyrgyz, even inferring that it was the root cause underlying the outbreak of the clashes. For example, the New York Times on June 14, 2010, reported: “The most notable distinction, the one that is most responsible for the animosities that led to the recent violence, Central Asian experts say, is economic: Kyrgyz are traditional nomads, while Uzbeks are farmers. That divide has translated today into a wide class distinction, as Uzbeks have prospered and now own many of the businesses in southern Kyrgyzstan, which has engendered resentment” (Kramer, 2010). Bond and Koch (2010: 535) note that, “Although the fighting was primarily between ethnic Kyrgyz and Uzbeks, the basis for much of the tension between the two groups is not ethnicity per se..., but rather economic and class differences.” Such a portrayal implies that the violence is considered to be the result of horizontal inequalities and that Uzbeks are economically better off. This makes Kyrgyzstan a particularly interesting case to investigate, as it is the minority group that is supposedly better off; whereas in many other countries, in which ethnic inequality has been studied, it is the majority group that is privileged (Baulch, et al., 2007, Gradín, 2009, Gustafsson and Shi, 2003, van de Walle and Gunewardena, 2001). As suggested by Chua (2003), countries with an economically dominant ethnic minority may be particularly subject to ethnic hatred and violent conflict.

Previous research on Kyrgyzstan shows that ethnicity is one of the factors that helps explain welfare differences between households in Kyrgyzstan. Beside household size, educational attainment, employment status, and residence in certain regions, ethnicity is 
usually found to be a significant determinant of welfare (measured as per capita expenditure), at least in some regions of the country and in some years (Ackland and Falkingham, 1997, Anderson and Becker, 1999, Anderson and Pomfret, 2000). However, all these studies use ethnicity dummies among several other variables in their welfare regressions, which only allows to interpret the ethnicity coefficients as a discrimination effect or cultural bias. None of them explicitly analyses welfare differences between ethnic groups.

In our empirical analysis we use household survey data from the Kyrgyz Integrated Household Survey (KIHS). We define three alternative welfare measures: (1) per capita household expenditure; (2) an asset index; and (3) the self-reported value of the house. For the most part, we restrict the empirical analysis to the south of Kyrgyzstan and to the two ethnic groups of Kyrgyz and Uzbeks. We find that Uzbeks do not differ much from Kyrgyz in terms of welfare, when measured by either per capita expenditure or asset indexes. Uzbeks have slightly lower expenditure in both urban and rural areas, which is primarily explained by differences in the characteristics of the two groups. Uzbeks also have slightly fewer assets than Kyrgyz in urban areas, but more in rural areas. They also report having more valuable houses in urban areas. The decomposition of these asset and house value gaps shows that they are not due to differences in the characteristics of Kyrgyz and Uzbeks but, instead, to structural differences.

The main contribution that we seek to make to the literature is twofold. First, the choice of welfare indicator may be decisive in studies on horizontal inequality. If we relied on expenditure and asset data, we would conclude that there is not much of a difference between the two groups, or that Uzbeks are worse off. However, Uzbeks do fare better in the most visible of our welfare indicators, house value. We argue that it is these visible aspects of life that are most likely to form the perceptions of people about another ethnic group's standard of living, which may, in turn, trigger violent conflict. Second, decomposing welfare differentials may be as important as determining them. The knowledge that one group is better off than another is an essential insight, but it leaves open where such inequality comes from and how it can be tackled. The Oaxaca-Blinder decomposition promises to be a useful tool for this purpose.

The remainder of this paper is organized as follows. In the next section, we elaborate on the situation of the Uzbek community in Kyrgyzstan. We then present the data that we use for our empirical analysis. After that, we define a set of alternative welfare measures. Subsequently, we measure horizontal inequality between Kyrgyz and Uzbeks and decompose the welfare gap between the two ethnic groups. We summarise and discuss our results in the conclusion. 


\section{Background: Uzbeks in Kyrgyzstan}

Kyrgyzstan was among the most ethnically heterogeneous Soviet republics at the time of the collapse of the Soviet Union (Fumagalli, 2007b). In 1989, the three largest ethnic groups were the Kyrgyz (60 percent), Russians (16 percent), and Uzbeks (14 percent). Numerous other ethnic groups, including, among others, Dungans, Turks, Uigurs, and Tajiks, lived within the boundaries of what is today's Kyrgyzstan; but they accounted for marginal shares of the total population. Today, the Kyrgyz make up 71 percent, the Uzbeks 14 percent, the Russians 8 percent, and all other ethnicities are each around one percent or less (NSC, 2009). The two largest minority groups are spatially concentrated: Uzbeks mainly live in the south of the country in the oblasts of Osh, Djalalabad and Batken - close to the border with Uzbekistan while Russians mainly live in the north.

Traditionally, the Kyrgyz were a nomadic people engaged in animal breeding, whereas the Uzbeks were sedentary agriculturalists and urban-based craftsmen and traders (Fumagalli, 2007b, Matveeva, 2010, Spector, 2004, Tishkov, 1995). This implies a higher concentration of Uzbeks in the plains and of Kyrgyz in mountainous areas, which still prevails. Fumagalli (2007b: 216f.) calls this a "Soviet-induced balance between ethnic groups and ethnic stratification of labour”. After the collapse of the Soviet Union, the Uzbeks are said to have “made the transition to business ownership more readily" (Bond and Koch, 2010: 535) than the Kyrgyz, which allegedly makes them form the core of a relatively more prosperous class in the south today. Many media reports reinforce this perception. Luke Harding (2010), writing for the Guardian, describes the Uzbeks as "better off than their once nomadic Kyrgyz counterparts, running most businesses and living in bungalows with courtyards and apricot trees”. Countering the media, Matveeva (2010) calls the perception of richer and more privileged Uzbeks a stereotype. In the same manner, Melvin (2011) notes that ethnic differentiation in southern Kyrgyzstan is reinforced by the organisation of the economy, i.e. Uzbeks in urban centres and Kyrgyz in rural areas, but he does not relate this to the eruption of violence. He merely claims that "growing economic pressures increasingly came to bear at ethnic contact points”, such as markets (Melvin, 2011: 21).

It appears to be undoubtful that, whatever their economic position, Uzbeks are disadvantaged in the political and social spheres of life. After the collapse of the Soviet Union, president Askar Akayev showed to be committed to the ideology of a multiethnic society, as reflected in his slogan "Kyrgyzstan is our common home” (Fumagalli, 2007b, Matveeva, 2010, Melvin, 2011). At the beginning of his rule, improving ethnic relations was one of his priorities and he was able to build a broad coalition, which was inclusive of both 
nationalist factions as well as ethnic minorities (Fumagalli, 2007a, Melvin, 2011). For example, he formed the Assembly of the People of Kyrgyzstan, which drew together leaders from almost 30 ethnic communities and gave them a voice in the political process (Spector, 2004). However, over the course of his presidency he became more and more authoritarian and less concerned with equal opportunities for different ethnicities. For example, ahead of the 2000 presidential elections, he introduced a language law which required the president to speak the Kyrgyz language, thus disqualifying several challengers (Spector, 2004). Uzbeks were reportedly very concerned that an even more nationalist-oriented president might replace Akayev and thus supported him despite increasing frustrations and grievances (Fumagalli, 2007a, Melvin, 2011, Spector, 2004). When Bakiyev became president in 2005, the situation of the Uzbek community deteriorated indeed, as he exposed open nationalist rhetoric and applied exclusive and intransparent personnel politics in the south (Matveeva, 2010).

Since 1990, there have been two major episodes of violent conflict between ethnic Uzbeks and Kyrgyz. The first episode occurred in June 1990 when mass riots broke out in the city of Osh and neighbouring areas. About 170 people (mostly Uzbeks) were killed, with many more injured (Tishkov, 1995). There was no single cause to the violence. One of the triggers was the fact that Uzbeks claimed the local government had awarded plots of land and housing disproportionately to Kyrgyz and that they had prematurely occupied the land (Bond and Koch, 2010). Additional factors seem to have been a struggle to gain control over power structures, increased social differentiation along city-village lines, and high rates of unemployment (Tishkov, 1995). After this episode of violence, the Uzbek community in Kyrgyzstan was initially considered “a potential hotbed for conflict” (Fumagalli, 2007b: 214). To what extent this is true is debatable. Data from the Survey of Conflict Prevention and Cooperation conducted by the World Bank in 2004 show that three quarters of the sampled households (or, 78 percent of Kyrgyz households and 73 percent of Uzbeks households in the sample) reported somewhat good or very good relations among people of different ethnic groups. Further, 57 percent of the sample (54 percent of Kyrgyz and 74 percent of Uzbeks) stated that conflict within the country over the next few years was not likely at all. Only 2 precent said that conflict was highly likely.

The second major episode of violence occurred in June 2010 in Osh, in which around 470 people were killed; the majority Uzbeks. About 400,000 fled temporarily from their homes, partly to neighbouring Uzbekistan, and a large number of properties were destroyed (Bond and Koch, 2010, Kyrgyzstan Inquiry Commission, 2011, Melvin, 2011). ${ }^{2}$ The cause of

\footnotetext{
${ }^{2}$ The exact number of victims and refugees is controversial. Different sources provide different numbers.
} 
these events is not entirely clear as the conflict did not appear to be spontaneous but may have been triggered by a series of coordinated attacks carried out by separate groups of armed men. In the beginning, Kyrgyzstan's interim government, under the leadership of Roza Otunbayeva, accused Bakiyev, who was ousted that April and had fled to Belarus, of having organised the clashes in order to destabilise the new government. No evidence has been presented to support this claim (Melvin, 2011).

The conclusion of a national commission formed by the then interim government states that Uzbek community leaders and members of the Bakiyev regime were responsible for the violence (Osmonov, 2011). An Independent International Commission of Inquiry did not identify any individuals responsible for the crimes. However, it emphasizes the awkward political situation that followed Bakiyev's ouster, during which followers of the interim government, supporters of the Bakiyev regime, and Uzbek community members struggled for power. It refers to a number of situations in which Uzbek community leaders demanded more political representation of Uzbeks, which was misunderstood by some as a demand for autonomy (Kyrgyzstan Inquiry Commission, 2011). Human Rights Watch reports that Uzbek and Kyrgyz crowds clashed following a fight between several men of both ethnic groups, with Uzbeks responsible for many of the initial attacks. Later, the balance reportedly shifted and ethnic Kyrgyz descended on Uzbek neighbourhoods, which made the events an 'interethnic conflict' (Human Rights Watch, 2010). Melvin (2011: 26) objects to this view and calls the events "an incident of ethnic violence within a broader conflict", which involves a wide range of political forces and social groups. He puts much weight on the rise of Kyrgyz nationalism. Yet, he acknowledges that once fighting started ethnicity became a defining factor of the violence, which reflected underlying tensions between the two communities. ${ }^{3}$

\section{Source of Data}

The data we use in this paper is from the Kyrgyz Integrated Household Survey (KIHS), which is conducted by the National Statistical Committee (NSC) of the Kyrgyz Republic. This survey annually covers close to 5,000 households since its inception in 2003. The sampling procedure is stratified, multistage random sampling, and the survey is representative at the national, rural/urban, as well as oblast (province) levels. There are 15 strata in total, corresponding to the urban as well as rural areas of the seven oblasts plus the capital. The

\footnotetext{
${ }^{3}$ It is debated whether the two mentioned incidents can be referred to as 'interethnic conflict' (Tishkov, 1999). In fact, the first reports about the 1990 events were not referred to as a conflict between Uzbeks and Kyrgyz but rather as the 'Osh conflict' (Tishkov, 1995, 1999). As mentioned, the 2010 violence seemed to be organised and triggered by a series of attacks by several groups of armed men. Nevertheless, in both cases the incidents took an interethnic turn and manifested themselves along ethnic lines (Fumagalli, 2007b).
} 
KIHS includes information on demographics, education, health, internal migration, employment, household expenditure, income, housing conditions, and assets. We were provided by NSC with KIHS data for all years between 2003 and 2010.

In our empirical analysis, we use data for the years 2005, 2007, and 2009 - all these years are pre-2010 observations, which is important as violence in 2010 is highly likely to have affected the welfare distribution in the population, at least in the southern part of the country. Importantly for us, information on ethnicity was collected in the KIHS only through 2005. ${ }^{4}$ However, the survey is a rotating panel, with a maximum substitution of 25 percent of households in each year. We assign the ethnicity reported in 2005 to those households that are part of the panel sub-samples in later years. Thereby, we can identify the ethnicity of 70 percent (3,384 out of a total of 4,803 households) of the 2007 sample and 57 percent $(2,821$ out of a total of 4,984 households) of the 2009 sample. We test for the prevalence of attrition bias following the example of Falaris (2003). Unlike Falaris, who used longitudinal data for Peru, Côte d'Ivoire and Vietnam, we find that there are differences in the slopes of the coefficients between stayers and attritors when we run welfare equations in the form of the below equation (2). This means that attrition is not random and that our 2007 and 2009 subsamples are no longer representative of the total population. Thus, we cannot draw conclusions for the population at large, but only for stayers. We identify in what respects these stayers differ from attritors by estimating attrition equations as in Fitzgerald et al. (1998). Stayers are more likely than attritors to live in rural areas and to be engaged in agriculture. They also tend to have more children and older household heads.

In terms of ethnicity, which is self-reported in the KIHS, we distinguish between Kyrgyz, Uzbek and Russian-headed households and pool all other ethnic groups. Households in Kyrgyzstan tend to be monoethnic. Based on KIHS data, among the households headed by Kyrgyz, 98 percent are married to Kyrgyz. Among Russian and Uzbek headed families, the share of intra-ethnic marriages is about 90 percent. Therefore, we consider the ethnicity of the household head to be a reliable proxy for the ethnicity of all other household members.

Table 1 illustrates the distribution of sample households in the respective years in rural and urban areas as well as in the north (composed of Chui, Issyk-Kul, Naryn, and Talas oblasts as well as Bishkek city) and south (composed of Batken, Jalal-Abad and Osh oblasts) of the country. It becomes clear that Uzbek households are concentrated in the south, while Russians and other ethnic groups mostly live in the north. Since we are interested in the economic differences between Uzbeks and Kyrgyz, we restrict most of the below

\footnotetext{
${ }^{4}$ In informal talks with experts close to NSC, we were told that ethnicity information was no longer collected because it was considered to be politically too sensitive.
} 
measurement and decomposition of welfare differentials to the south, while omitting Russians and others. We thereby assume that, for any grievances potentially leading to violent conflict, it is only these differences between Uzbeks and Kyrgyz residing in the south that matter. In the context of strong internal migration (Ablezova, et al., 2009, UNDP, 2009), this may not seem to be a convincing assumption. We release the assumption and make use of the data from the entire country in the sensitivity section.

Throughout this paper, we specify survey settings, such as strata and primary sampling units. However, for most of the calculations, we do not use sampling weights even though the KIHS data includes such information. Those weights appear questionable to us as they increased substantially between 2003 and 2005, relatively more so for Uzbeks than for the other ethnic groups, and then stayed much higher for this particular ethnicity. ${ }^{5}$ We were told by NSC that the calculation of weights takes into consideration the sampling probability of primary sampling units in each stratum and the sampling probability of households in these units. These weights are then modified in order to give a realistic picture of different age groups (children, working age adults, elderly) in society, but they reportedly do not control for ethnicity. A disproportionate increase of weights for Uzbek households would then only make sense, if the age structure of Uzbeks changed dramatically over time, if the number of Uzbeks decreased in the sample, or if Uzbek households became smaller and smaller. None of these options is the case and, hence, we prefer not to use weights in order to ensure that they do not influence our results in undesirable ways. This implies, of course, that the below estimates, especially the descriptive statistics, are not representative for the total population but only for the sampled households. However, we are already using non-random sub-samples for these years, so we cannot obtain representative figures for 2007 and 2009. Nevertheless, whether or not ethnicity is related with welfare should not be affected. In the below sensitivity section, we repeat our main analysis with the use of weights.

\section{Measurement of Welfare}

In this section, we define three alternative measures of welfare and describe how they are constructed. Our first indicator is per capita household expenditure, which is the most commonly applied welfare measure in developing countries and which has also been widely used in other studies of ethnic inequality. However, we argue that, for the purpose of this paper, expenditure may not be the most appropriate measure of welfare because it is not easily observable to others and, hence, perceptions may not come about on the basis of expenditure

\footnotetext{
${ }^{5}$ For example, the average weight for the Uzbek group increased by a factor of 4.9 between 2003 and 2005, while the average weight for the other ethnic groups increased by about 2.7 .
} 
levels. Instead, perceptions about welfare levels may be formed on the basis of more visible goods, such as household assets. ${ }^{6}$ Our second measure is therefore an asset index in the sense of Sahn and Stifel (2000, 2003) and Filmer and Pritchett (2001). Given that the components of a typical asset index (such as ownership of refrigerators or radios) may still not be publicly visible (though more visible than expenditure), we consider the self-reported value of the house as a third welfare measure. People can easily assess the features of houses of others, even of strangers, which makes this measure of welfare particularly relevant for studies of horizontal inequality.

Per capita expenditure of households is calculated on the basis of very detailed information in the KIHS. We construct the consumption aggregate underlying our welfare measure in line with standard practice (Deaton and Zaidi, 2002). It comprises food and nonfood consumption. Food consumption is the monetary value of consumed food, which comprises of purchased food products, home-produced food products, and food received as gifts. The nominal food consumption of households is deflated by the food price Paasche index, which takes into consideration regional and urban/rural price differences. ${ }^{7}$ Non-food consumption includes expenditures on clothing, utilities, services, and other recurrent nonfood items. Housing rents and expenditures on durable goods are excluded from the consumption aggregate, but the user value of owned durable goods is part of it. The consumption aggregate does not control for economies of scale. We obtain per capita expenditure by dividing the consumption aggregate by the number of household members. ${ }^{8,9}$

Our asset index is constructed using 17 components that represent ownership of key durables (i.e. music player, color TV, video recorder/player, photo camera, washing mashine, vacuum cleaner, auto and motor transport, fridge, bedroom furniture, kitchen furniture, cell phone, and landline phone), housing conditions (i.e. central heating, access to clean water, and clean toilet), and access to basic infrastructure (reliable energy supply and less than five minutes walk to the nearest bus station). We apply a principal component analysis to construct our index, in line with Filmer and Pritchett (2001). We execute a linear transformation of the

\footnotetext{
${ }^{6}$ This borrows from the literature on conspicuous consumption, which argues that the consumption and display of particular, so called conspicuous, goods communicates information about economic and social status (Charles, et al., 2009). Conspicuous goods are those goods whose consumption is easily observable in anonymous social interactions (Charles, et al., 2009, Veblen, 1924).

${ }^{7}$ For each year, we calculated a regional price difference for 15 different regions, corresponding to the 15 strata used for sampling.

${ }^{8}$ Respondent households keep diaries of food expenditure and consumption for 14 days each quarter of the year. Some households drop out of the sample in the course of the year so that there is information for them for less than four quarters. We do not impute information for them but delete them from the sample.

${ }^{9}$ Using per capita expenditure instead of per adult equivalent expenditure is the common practice of welfare measurement in Kyrgyzstan by NSC and the World Bank.
} 
asset index in order to have a more standardized measure, which is anchored at a minimum of one.

The house value is the self-assessed sales price of a household's dwelling at the time of the interview. ${ }^{10}$ More than 90 percent of households in Kyrgyzstan own the dwelling they live in, so there is a good chance that people indeed know their house's value. In the data, the households' assessment of the house price in urban areas seems to be accurate when compared to actual market prices, as, for example, reported on the real estate site of the information portal allkyrgyzstan. ${ }^{11}$ However, given that two thirds of the population live in rural areas, where the house market functions more poorly, we cannot be certain that the selfassessed price reflects the factual value in these areas. Hence, we will first run all house value estimations using rural and urban areas together and then distinguish between them in the sensitivity section. ${ }^{12}$ A clear distinction between urban and rural areas is indispensable for another reason as well: Kyrgyz and Uzbeks have largely separate housing markets in urban areas. Uzbeks usually live in so-called mahallas, which are made up by numerous detached houses that are home to, potentially, several families. Very few Kyrgyz live in these mahallas, but, instead, they mostly live in multi-storey apartment buildings in other areas of the towns (Liu, 2012). We discuss the implications of such geographic segregation of the housing situation, which does not exist in rural areas, below.

Table 2 provides descriptive statistics for the three welfare measures. For the two monetary measures, i.e. household expenditure and house value, we calculated real values (in 2005 prices). We also excluded outliers, which we defined as those welfare values greater than three standard deviations from the mean. As the table shows, all welfare measures increased on average over time. House values, in real terms, apparently increased dramatically over the period of interest, which is confirmed by UNECE (2010). The table also reports the pairwise correlations between our welfare measures. The association between per capita expenditure and the asset index is between 36 and 42 percent over the years. The correlation between per capita expenditure and house values is substantially lower and ranges from 21 to 31 percent. The asset index and the house value are correlated to a larger extent, between 37 and 45 percent.

\footnotetext{
${ }^{10}$ We considered using the value of automobiles in addition, since these are very visible and potentially status signalling goods as well. However, the share of households that reported to have an automobile is very low; it ranges from 11 percent in 2005 to 18 percent in 2009.

${ }^{11}$ See http://www.allkyrgyzstan.com/business/real-estate.htm (accessed on October 12, 2012).

${ }^{12}$ Non-reporting, comprising both refusals and difficulties to assess the house value, varies from 3 to 21 percent across the years. However, we do not find any pattern in non-reporting: Both rural and urban households are equally likely to not report; non-reporting does also not depend on gender, ethnicity, age, or educational level of the household head.
} 


\section{Determining and Decomposing Welfare Differentials}

In this section, we identify potential welfare differentials between Kyrgyz and Uzbeks, then apply the Oaxaca-Blinder (Blinder, 1973, Oaxaca, 1973) decomposition in order to shed some light on the sources of such differentials. The basic idea of this method is to decompose the mean welfare gap between two groups into a component attributable to differences in the observed characteristics of the groups (characteristics effect, or endowments effect) and a component attributable to between-group differences in the returns to given individual characteristics (coefficients effect, or discrimination). Following Neumark (1988), the decomposition, based on Ordinary Least Squares (OLS) regression of welfare functions, is as follows:

$$
\bar{W}_{K}-\bar{W}_{U}=\beta\left(\bar{X}_{K}-\bar{X}_{U}\right)+\left[\bar{X}_{K}\left(\beta_{K}-\beta\right)-\bar{X}_{U}\left(\beta_{U}-\beta\right)\right]
$$

(Total difference $=$ Characteristics effect + Coefficients effect $)$

where $\bar{W}$ represents mean welfare, usually measured in logarithmic terms, $\bar{X}$ is a vector of the mean characteristics, and $\beta$ are the regression coefficients, which reflect the returns to a unit change in characteristics. The subscripts $K$ and $U$ indicate Kyrgyz and Uzbek, respectively. The first term on the right-hand side of equation (1) is the characteristics effect, and the second term the coefficients effect.

The underlying welfare function takes the simple form

$$
W_{i g}=\beta_{g} X_{i g}+\varepsilon_{i g}
$$

where $W_{i g}$ indicates welfare of household i belonging to ethnic group g ( $g=$ Kyrgyz, Uzbek), $X_{i g}$ is the vector of household characteristics of household i belonging to group g, and $\varepsilon_{i g}$ is the error term. Essentially, this function is estimated separately for Kyrgyz and Uzbeks, which provides the parameter estimates $\beta_{K}$ and $\beta_{U}$. The function is additionally estimated with the sample of Kyrgyz and Uzbeks pooled together in order to obtain the parameter $\beta$. These three parameter estimates as well as the group means for welfare and the household characteristics are then used to perform the decomposition of equation (1).

In a first step, we estimate equation (2). As explanatory variables, we include variables that are identified in the literature as important and statistically significant determinants of living standards in Kyrgyzstan (Ackland and Falkingham, 1997, Anderson and Becker, 1999, Anderson and Pomfret, 2000). Specifically, we control for age and gender of the household head, and household composition (number of pre-school children, school children, working age adults, and elderly members). With regard to human capital, we use the average of 
schooling years of all adult household members. ${ }^{13}$ We consider this to better reflect the stock of human capital of households than education of the household head only, as many heads are relatively old. We control for the hours per week worked in services per employed household member. We also control for the ownership of irrigated and cultivated land (in hectares) as well as ownership of livestock. With regard to the latter, we calculate sheep equivalent units (SEU) in order to be able to express different types of livestock in a common unit. ${ }^{14}$ We include dummy variables for rural areas as well as the main administrative regions in the south of the country, i.e. Batken, Jalalabad, and Osh oblasts. Table 3 outlines the definitions of these variables. Table 4 provides survey means for these variables for the total population of the south of Kyrgyzstan as well as for Kyrgyz and Uzbeks separately.

In Table 5, we provide the results for estimating equation (2) using OLS regression. By running the regressions for Kyrgyz and Uzbeks, we allow the coefficients to differ for the two groups. We estimate equation (2) for 2005, 2007, and 2009, as well as for the pooled sample (including year dummies). Given that the results do not differ by much, Table 5 reports the pooled results for the sake of simplicity. In general, our results are in line with previous research in the sense that household composition, educational attainment, employment status, and residence in certain geographical areas are the most significant determinants of household welfare in Kyrgyzstan. However, these variables, together with the other control variables included, explain differences in per capita expenditure much better than differences in assets and the house value. Whereas the R-squared is about 67 percent in the first case, it is between 23 and 42 percent in the other cases, which are still reasonable values for cross-sectional estimations with such a sample size. Chow tests reject identical parameters for all three welfare measures $(F=3.73$ for expenditure, $F=3.07$ for asset index, $\mathrm{F}=2.81$ for house value), which means that Kyrgyz and Uzbeks have significantly different coefficients.

In a next step, we therefore perform the decomposition of equation (1) in order to determine the magnitude of the welfare differentials between Kyrgyz and Uzbeks and to investigate how much of these differentials are due to differences in characteristics and how much are due to differences in the coefficients (Table 6). We report the results separately for

\footnotetext{
${ }^{13}$ Years of education were inferred from the level of education obtained. We take the schooling reform of 1989 into consideration, as this increased primary and secondary schooling to last 11 years, up one year from the previous ten.

${ }^{14}$ Livestock units are an exchange ratio among livestock species obtained by converting the body weight into the metabolic weight. We use the sheep equivalent units scale from the World Bank's Livestock Review 2007 for Kyrgyzstan and adjust the scales for other types of animals using the Mongolian case. The equivalence scale is in line with the concept of tropical livestock units, which are often used for African countries. On this matter, see http://www.fao.org/ag/againfo/programmes/en/lead/toolbox/Mixed1/TLU.htm. The standard used for one SEU is one sheep. Five sheep correspond to one cattle.
} 
the three welfare measures and do not pool the data here but, instead, run the decomposition for each one of the three years of interest. We first focus on the differentials per se. We report the difference in the welfare means between the two groups as the mean for Kyrgyz minus the mean for Uzbeks. Hence, a positive difference implies that Kyrgyz are better off than Uzbeks, and a negative difference implies the opposite. We obtain a consistent picture over time: 1) expenditure of Uzbeks is lower compared with that of Kyrgyz and this difference is statistically significant in two out of three years, 2) Uzbeks have more assets than Kyrgyz, and this gap is statistically significant in two out of three years, and 3) the value of houses is higher for Uzbeks compared with that of Kyrgyz, and this is statistically significant in all years.

Given that we here analyse urban and rural households together, it could be that these identified differences, and in particular the ethnic gap in house values, are driven by the fact that the majority of Uzbeks live in urban areas, while Kyrgyz tend to live more in rural areas (see Table 1). We therefore repeat the exercise separately for rural and urban areas (columns (2) and (3) of Table 7). In urban areas, per capita expenditure and the asset index of Uzbeks are lower than those of Kyrgyz. In rural areas, Uzbeks have higher asset indexes but lower expenditure compared with Kyrgyz. Again, this pattern is consistent over time, even though the welfare gaps are not in all cases statistically significant. The house values of Uzbeks are clearly higher than those of Kyrgyz in both urban and rural areas. However, there are only few observations for rural Uzbeks in the sample, and so, measurement error seems highly likely.

When we look at the magnitude of the welfare differentials, it is clear that the most striking difference between Kyrgyz and Uzbeks is that the latter have much more valuable houses. We here elaborate on possible explanations for this stark house value differential. On the one hand, it could, of course, be that the observed differential is due to systematic misreporting of one of the ethnic groups. Either Kyrgyz may report house values that are too low, or Uzbeks may report house values that are too high. On the other hand, it could be that the differential is real and that it stems from supply constraints in the Uzbek housing market (for example, in the form of discrimination in the provision of construction permits for houses in mahallas), from a different way of construction of Uzbek houses (for example, in the form of using more expensive, anti-seismic material), or from the fact that Uzbeks have larger dwellings than Kyrgyz. The latter point appears most likely, at least for the case of urban areas, where Uzbeks tend to live in houses and Kyrgyz in apartments, as mentioned above. We therefore compare the total area of the dwelling, the living area of the dwelling, the number of rooms as well as the per capita total area of the dwelling of Kyrgyz and Uzbek 
households. We report these for the year 2005 and disregard the other years, because there are essentially no changes over time.

We find that Uzbeks indeed have larger houses than Kyrgyz in urban areas, whereas there is no difference in rural areas (Table 8). Uzbek urban houses are significantly larger and have more rooms. This is a very visible aspect of people's standard of living, which can easily drive perceptions about interethnic welfare differentials and enhance grievances among the relatively deprived group. It must be noted, however, that Uzbek households are on average larger, such that the per capita house area is not significantly different from that of Kyrgyz households. Importantly, this does not translate into a loss of significance in the per capita value differential. The house value is still significantly different between Uzbeks and Kyrgyz when we compare it in per capita terms (not reported). It may seem surprising that Uzbeks have (absolutely) larger and more valuable houses, even though they fare worse in terms of household expenditure. A Central Asian proverb may help explain this: "When a Kyrgyz man becomes rich, he takes a second wife. When an Uzbek man becomes rich, he builds a second house." This proverb implies that Uzbeks have strong preferences for investing in their houses, whereas Kyrygz may prefer to spend their resources on other ends.

We now turn to the Oaxaca-Blinder decomposition results in Table 6. As mentioned above, the difference in mean welfare is not in all cases statistically significant and, hence, we do not interpret the decomposition results of these insignificant differentials. With regard to the significant differentials, we find that differences in the characteristics between Kyrgyz and Uzbek households make up for most of the mean gap in expenditure and assets. For example, the positive characteristics effect for expenditure in 2007 implies that, if Kyrgyz and Uzbeks had the same OLS coefficients, the (logarithmised) welfare differential would be 81 percent of 0.0855 , solely due to differences in characteristics. If, in contrast, they had the same characteristics, about four fifths of the welfare differential would disappear.

In contrast, the difference in the house value cannot be well explained by differences in characteristics. Here, it is differences in the coefficients between the two groups that account for the welfare differential. If Kyrgyz and Uzbeks had the same coefficients, the differential in the (log) house value would be only 14.3 percent of -0.4934 in the year 2005. In the later years, the characteristics effect still looses in relevance, and in 2009, even becomes negative. This implies that, if Kyrgyz and Uzbeks had the same coefficients, the differential in the (log) house value would turn around, and it would now be Kyrgyz households that would have higher house values. We cannot rule out that this time trend is because of the nonrandom sub-samples of 2007 and 2009, which we investigate further in the below sensitivity section. Furthermore, as pointed out, we are aware that there is large potential for 
misreporting in the house value data, especially for rural areas. Hence, we analyse the decomposition results for urban areas alone below.

Summarising what we find so far, Uzbeks do not unequivocally differ from Kyrgyz in terms of per capita expenditure as well as assets. However, when they differ, Uzbeks have lower expenditure, but more assets. In both cases, the decomposition shows that these welfare differentials are mostly due to differences in the characteristics of the groups. If Kyrgyz and Uzbeks had the same characteristics, the welfare differential would (almost) disappear. In contrast, Uzbeks report clearly higher house values than Kyrgyz, and this is always statistically significant. This particular welfare differential is not due to characteristics but, instead, to differences in the coefficients of Kyrgyz and Uzbeks.

\section{Sensitivity}

In the following, we run a number of sensitivity checks to see whether these results hold when we take sampling weights into account and use different samples. We limit ourselves to reporting the main results of the Oaxaca-Blinder decomposition, namely the difference in mean welfare and the contributions of the characteristics effect as well the coefficients effect to this difference (Table 7). Column (1) reproduces our basic results from Table 6. In column (2), we present the decomposition results for urban households and in column (3) for rural households. In terms of expenditure, Uzbeks are confirmed to be worse off than Kyrgyz, in both urban and rural areas, and most of this welfare gap is again found to be due to differences in the characteristics of the two ethnic groups. The decomposition results for assets, separately for urban and rural areas, are very different from those in column (1). Whereas we previously showed that asset differentials are due to a characteristics effect, we now see that, when we perform the decomposition separately for urban and rural areas, they are, instead, due to differences in the coefficients of Kyrgyz and Uzbeks. This is puzzling at first glance. However, it can be explained by the fact that Uzbeks are better off than Kyrgyz in rural areas but worse off in urban areas. Pooling urban and rural areas then leads to misleading decomposition results.

Turning to the house value differential, we do not pay much attention to the results for rural areas, because, as we previously noted, we cannot be sure about the reliability of the self-reported house values of rural households. For urban areas, we find that the coefficients effect is still larger than the characteristics effect, but it is now substantially lower in 2005 and 2007 than in our basic results. In 2005, the coefficients effect makes up close to two thirds of the total difference in house values. This means that, if Kyrgyz and Uzbeks had the same characteristics, the gap in house values would be reduced by about one third. In 2009, 
however, the magnitude of the coefficients effect is again much higher and close to the one estimated in our basic results.

In column (4), we run the decomposition using sampling weights, which we had ignored in our estimations so far. We described our doubts about the KIHS weights above, but we nevertheless acknowledge that it may be essential to use them, for the following reason. In comparison with the 2009 Census, in which Uzbeks made up 14 percent of the population, they are under-represented in the KIHS samples (see Table 1). Hence, higher weights for Uzbeks may indeed make sense, even though this does not explain the extraordinary increase in their weights before 2005. In any case, including weights leads to even more insignificant differences in mean expenditure and mean assets between Kyrgyz and Uzbeks, compared with our basic results. Only in 2005, we observe a significant welfare gap between the two ethnic groups in terms of assets. As in column (1), Uzbeks are found to have fewer assets than Kyrgyz. Yet, the decomposition now shows that this difference is mostly due to different coefficients, rather than different characteristics. This is in line with the findings in columns (2) and (3). The results for house values are qualitatively unchanged compared with our basic results.

In column (5), we add Kyrgyz and Uzbek households living in northern Kyrgyzstan to our sample. This relaxes the assumption made above, that it is differences in welfare among southern households alone that potentially drive frustration against another ethnic group. As was shown in Table 1, there are very few Uzbeks living in the north and, hence, we now essentially compare Kyrgyz living anywhere in the country to Uzbeks living in the south. We now find that there is no asset index gap at all, while there is a significant expenditure gap in 2005 and 2007. Uzbeks are then clearly worse off than Kyrgyz in terms of per capita expenditure and this is primarily explained by differences in the characteristics between the two groups. In terms of the house value, Uzbeks are again found to have more valuable houses, and the contribution of the coefficients effect is still larger than that of the characteristics effect, though somewhat reduced.

In column (6), we reduce the sample to those households that were interviewed in all three years. This is to rule out the possibility that changes over time, observed in Table 6, are driven by sample attrition. Note that the 2009 results are then identical to those in column (1), because we identify the 2009 sample households in the samples of 2005 and 2007. Expenditure again turns out to be only insignificantly different between Kyrgyz and Uzbeks, and Uzbeks are shown to have significantly higher asset indexes (at least, at a marginal level). As in our basic results, the characteristics effect makes up for 63 percent or more of the total difference in the mean asset index. This share increases over time in line with column (1), 
which implies that sample attrition is not driving these results. This is confirmed for the case of the house value, as the respective findings in columns (1) and (6) are very similar.

\section{Conclusion}

In this paper, we measure welfare gaps between Kyrgyz and Uzbek households in Kyrgyzstan. We also decompose these welfare gaps in order to better understand the sources of ethnic inequality. This is motivated by the fact that there have been two major episodes of inter-ethnic violent clashes since 1990 and that economic disparities between the two groups have been used to explain the outbreak of violence. Uzbeks are reported to be more prosperous than Kyrgyz, which is in turn assumed to result in resentment among the latter. We measure welfare with the help of three alternative indicators, i.e. household expenditure, asset indexes, and house values.

With regard to household expenditure, we find that Uzbeks are not better off than Kyrgyz. They have, instead, consistently lower expenditure levels, across years, different regions of the country, and different sample sizes, though this is not always statistically significant. Decomposing the expenditure gap shows that differences in the characteristics of Kyrgyz and Uzbeks explain almost all of this gap. The Oaxaca-Blinder decomposition allows for even more disaggregated insights: It is mainly differences in household composition (i.e. more adults and elderly in the household) and ownership of livestock (i.e. less livestock) that explain the lower expenditure of Uzbeks.

Turning to the ownership of assets, we show that there is a clear difference between urban and rural areas. In towns, Kyrgyz are found to own more assets than Uzbeks (at least at a marginal significance level), but this pattern is inverted in villages. In both cases, the welfare gap is due to differences in the coefficients between the two groups. Last but not least, the value of houses reported by Uzbeks is clearly higher than that reported by Kyrgyz, which implies that Uzbeks may have larger houses, houses of better quality, and/or houses in more expensive locations. The decomposition again emphasises the dominance of the coefficients effect.

Disaggregation of the decomposition results for both assets and house values does not lead to clear insights which specific coefficients are at play. We get mostly insignificant results for all coefficients and, therefore, need to acknowledge the possibility that our decomposition results may be distorted. The model that we estimate does not explain the asset and house value variation as well as it explains expenditure variation. Omitting relevant characteristics (i.e. those that are partly correlated with welfare and the included explanatory variables) can erroneously lead to attributing their effect to the coefficients, as pointed out by 
Gunderson (1989). Even so, we believe that decomposing inter-ethnic welfare differentials is promising in studies of horizontal inequalities and hope to see further research along these lines.

So, what do we learn about horizontal inequality between Uzbeks and Kyrgyz? We are able to show that the choice of welfare measure matters a lot for studies on inequality between groups. Depending on which measure we use, we find that Uzbeks are either worse off or better off than Kyrgyz, or that there is no horizontal inequality at all. Had we relied on the most common welfare indicator used in developing countries, i.e. household expenditure, our conclusion would be that Uzbeks are certainly not better off. This would prove the display in the media completely wrong. However, looking at more visible welfare measures, such as the ownership of assets (in rural areas) and the value of the house, changes the picture. In particular, the house value clearly shows Uzbeks to be more prosperous - assuming that the reported house values are correct. We argue that inequality in such visible goods is much more worrying for the outbreak of violence than inequality in household expenditure. Even if two ethnic groups do not differ at all in terms of what they consume or what they earn, one group may feel seriously relatively deprived if the other group owns just one asset more - if this asset was easily observed. The deprived group may then assume that the other group was better off in all aspects of life. It appears that this could indeed be the case in Kyrgyzstan, where the perception of more prosperous Uzbeks may have been formed on the basis of Uzbek dominance in certain economic sectors - or, as shown here, house characteristics. Policy-makers could challenge the public perception of one group being better-off than the other by referring to quantitative results such as ours. Making the point that Uzbeks are not clearly more prosperous than Kyrgyz, but only have more valuable (and larger) houses, could make a difference for peace-making efforts. 


\section{Bibliography}

1. Ablezova, M., Nasritdinov, E., and Rahimov, R., 2009. The Impact of Migration on Elderly People. Grandparent-Headed Households in Kyrgyzstan. Help Age International Central Asia and Social Research Center, American University of Central Asia, Bishkek.

2. Ackland, R., and Falkingham, J., 1997. A Profile Of Poverty In Kyrgyzstan In: Falkingham, J., Klugman, J., Marnie, S., and Micklewright, J., (Eds.), Household Welfare in Central Asia. Macmillan Press, Basingstoke, pp. 81-99.

3. Anderson, K., and Becker, C., 1999. Post-Soviet Pension Systems, Retirement, and Elderly Poverty: Findings from the Kyrgyz Republic. MOCT-MOST Economic Policy in Transitional Economies 9, 459-478.

4. Anderson, K., and Pomfret, R., 2000. Living Standards during Transition to a Market Economy: The Kyrgyz Republic in 1993 and 1996. Journal of Comparative Economics 28, 502-523.

5. Baulch, B., Chuyen, T. T. K., Haughton, D., and Haughton, J., 2007. Ethnic Minority Development in Vietnam. Journal of Development Studies 43, 1151-1176.

6. Baulch, B., Pham, H. T., and Reilly, B., 2012. Decomposing the Ethnic Gap in Rural Vietnam, 1993-2004. Oxford Development Studies 40, 87-117.

7. Bhaumik, S. K., Gang, I. N., and Yun, M.-S., 2006. Ethnic Conflict and Economic Disparity: Serbians and Albanians in Kosovo. Journal of Comparative Economics 34, 754-773.

8. Blinder, A. S., 1973. Wage Discrimination: Reduced Form and Structural Estimates. Journal of Human Resources 8, 436-455.

9. Bond, A. R., and Koch, N. R., 2010. Interethnic Tensions in Kyrgyzstan: A Political Geographic Perspective. Eurasian Geography and Economics 51, 531-562.

10. Charles, K. K., Hurst, E., and Roussanov, N., 2009. Conspicuous Consumption and Race. Quarterly Journal of Economics 124, 425-467.

11. Chua, A., 2003. World on Fire. How Exporting Free-Market Democracy Breeds Ethnic Hatred and Global Instability. William Heinemann, London.

12. Deaton, A., and Zaidi, S., 2002. Guidelines for Constructing Consumption Aggregates for Welfare Analysis, LSMS Working Paper. World Bank, Washington DC.

13. Falaris, E. M., 2003. The Effect of Survey Attrition in Longitudinal Surveys: Evidence from Peru, Cote d'Ivoire and Vietnam. Journal of Development Economics 70, 133157.

14. Filmer, D., and Pritchett, L., 2001. Estimating Wealth Effects without Expenditure Data - Or Tears: An Application to Educational Enrollments in States of India. Demography 38, 115-132. 
15. Fitzgerald, J., Gottschalk, P., and Moffitt, R., 1998. An Analysis of the Impact of Sample Attrition on the Second Generation of Respondents in the Michigan Panel Study of Income Dynamics Journal of Human Resources 33, 300-344.

16. Fumagalli, M., 2007a. Framing Ethnic Minority Mobilisation in Central Asia: The Cases of Uzbeks in Kyrgyzstan and Tajikistan. Europe-Asia Studies 59, 567-590.

17. Fumagalli, M., 2007b. Informal Ethnopolitics and Local Authority Figures in Osh, Kyrgyzstan. Ethnopolitics 6, 211-233.

18. Gang, I. N., Sen, K., and Yun, M.-S., 2008. Poverty in Rural India: Caste and Tribe. Review of Income and Wealth 54, 50-70.

19. Gradín, C., 2009. Why is Poverty so High Among Afro-Brazilians? A Decomposition Analysis of the Racial Poverty Gap. Journal of Development Studies 45, 1426-1452.

20. Gunderson, M., 1989. Male-Female Wage Differentials and Policy Responses. Journal of Economic Literature 27, 46-72.

21. Gurr, T. R., 2000. Peoples versus States: Minorities at Risk in the New Century United States Institute of Peace Press, Washington DC.

22. Gustafsson, B., and Shi, L., 2003. The Ethnic Minority-Majority Income Gap in Rural China During Transition. Economic Development and Cultural Change 51, 805-822.

23. Harding, L., 2010. Uzbeks in Desperate Plea for Aid as Full Horror of Ethnic Slaughter Emerges, The Observer, http://www.guardian.co.uk/world/2010/jun/20/kyrgyzstan-uzbekistan-ethnic-civil-war (accessed October 19, 2012).

24. Human Rights Watch, 2010. "Where is the Justice?" Interethnic Violence in Southern Kyrgyzstan and its Aftermath. Human Rights Watch, New York.

25. Imai, K. S., Gaiha, R., and Kang, W., 2011. Poverty, Inequality and Ethnic Minorities in Vietnam. International Review of Applied Economics 25, 249-282.

26. Kijima, Y., 2006. Caste and Tribe Inequality: Evidence from India, 1983-1999. Economic Development and Cultural Change 54, 369-404.

27. Kramer, A. E., 2010. Kyrgyz Tensions Rooted in Class, Not Ethnicity, Experts Say, The New York Times, http://www.nytimes.com/2010/06/15/world/asia/15ethnic.html (accessed October 19, 2012).

28. Kyrgyzstan Inquiry Commission, 2011. Report of the Independent International Commission of Inquiry into the Events in Southern Kyrgyzstan in June 2010, http://reliefweb.int/sites/reliefweb.int/files/resources/Full_Report_490.pdf (accessed October 19, 2012).

29. Liu, M. Y., 2012. Under Solomon's Throne. Uzbek Visions of Renewal in Osh. University of Pittsburgh Press, Pittsburgh.

30. Mancini, L., 2008. Horizontal Inequality and Communal Violence: Evidence from Indonesian Districts. In: Stewart, F., (Ed., Horizontal Inequalities and Conflict. 
Understanding Group Violence in Multiethnic Societies. Palgrave Macmillan, Basingstoke, pp. 106-135.

31. Mancini, L., Stewart, F., and Brown, G. K., 2008. Approaches to the Measurement of Horizontal Inequalities. In: Stewart, F., (Ed., Horizontal Inequalities and Conflict. Understanding Group Violence in Multiethnic Soieties. Palgrave Macmillan, Basingstoke, pp. 85-105.

32. Matveeva, A., 2010. Kyrgyzstan in Crisis: Permanent Revolution and the Curse of Nationalism, Crisis States Working Paper Series. Crisis States Research Centre, London.

33. Melvin, N., 2011. Promoting a Stable and Multiethnic Kyrgyzstan: Overcoming the Causes and Legacies of Violence, Central Eurasia Project Occasional Paper Series. Open Society Foundations, New York.

34. Murshed, S. M., and Gates, S., 2005. Spatial-Horizontal Inequality and the Maoist Insurgency in Nepal. Review of Development Economics 9, 121-134.

35. Neumark, D., 1988. Employers' Discriminatory Behavior and the Estimation of Wage Discrimination. Journal of Human Resources 23, 279-295.

36. NSC, 2009. Population and Housing Census of the Kyrgyz Republic of 2009. Book 1. National Statistical Committee of the Kyrgyz Republic, Bishkek.

37. Oaxaca, R. L., 1973. Male-Female Wage Differentials in Urban Labor Markets. International Economic Review 14, 693-709.

38. Osmonov, J., 2011. Kyrgyz National Commission Claims Uzbek Community Leaders Responsible for June Violence, Central Asia-Caucasus Analyst.

39. Østby, G., 2008a. Inequalities, the Political Environment and Civil Conflict: Evidence from 55 Developing Countries. In: Stewart, F., (Ed., Horizontal Inequalities and Conflict. Understanding Group Violence in Multiethnic Soieties. Palgrave Macmillan, Basingstoke, pp. 136-159.

40. Østby, G., 2008b. Polarization, Horizontal Inequalities and Violent Civil Conflict. Journal of Peace Research 45, 143-162.

41. Sahn, D. E., and Stifel, D. C., 2000. Poverty Comparisons Over Time and Across Countries in Africa. World Development 28, 2123-2155.

42. Sahn, D. E., and Stifel, D. C., 2003. Exploring Alternative Measures of Welfare in the Absence of Expenditure Data. Review of Income and Wealth 49, 463-489.

43. Spector, R. A., 2004. The Transformation of Askar Akaev, President of Kyrgyzstan, Berkeley Program in Soviet and Post-Soviet Studies Working Paper Series. University of California, Berkeley.

44. Stewart, F., 2008. Horizontal Inequalities and Conflict: An Introduction and some Hypotheses. In: Stewart, F., (Ed., Horizontal Inequalities amd Conflict. Understanding Group Violence in Multiethnic Societies Palgrave Macmillan, Basingstoke, pp. 3-24. 
45. Tishkov, V., 1995. "Don't kill me: I am a Kyrgyz!": An Anthropologial Analysis of Violence in the Osh Ethnic Conflict. Journal of Peace Research 32, 133-149.

46. Tishkov, V., 1999. Ethnic Conflicts in the Former USSR: The Use and Misuse of Typologies and Data. Journal of Peace Research 36, 571-591.

47. UNDP, 2009. Human Development Report 2009. Overcoming Barriers: Human Mobility and Development. United Nations Development Programme, New York.

48. UNECE, 2010. Country Profiles of the Housing Sector. Kyrgyzstan. United Nations Economic Commission for Europe, New York and Geneva.

49. van de Walle, D., and Gunewardena, D., 2001. Sources of Ethnic Inequality in Viet Nam. Journal of Development Economics 65, 177-207.

50. Veblen, T., 1924. The Theory of the Leisure Class: An Economic Study of Institutions (reprint). Allen \& Unwin, London. 


\section{Appendix}

Table 1: Geographic distribution of households in the KIHS sample, 2005-2009

Sample size and percentage to total (in italic)

\begin{tabular}{|c|c|c|c|c|c|c|c|c|}
\hline & \multicolumn{2}{|c|}{ Kyrgyz } & \multicolumn{2}{|c|}{ Russian } & \multicolumn{2}{|c|}{ Uzbek } & \multicolumn{2}{|c|}{ Other } \\
\hline \multicolumn{9}{|c|}{2005} \\
\hline \multicolumn{9}{|l|}{ South } \\
\hline Urban & 574 & 12.4 & 81 & 1.7 & 279 & 6.0 & 80 & 1.7 \\
\hline Rural & 593 & 12.8 & 2 & 0.0 & 104 & 2.2 & 19 & 0.4 \\
\hline \multicolumn{9}{|l|}{ North } \\
\hline Urban & 1.087 & 23.4 & 520 & 11.2 & 30 & 0.6 & 160 & 3.4 \\
\hline Rural & 849 & 18.3 & 166 & 3.6 & 9 & 0.2 & 87 & 1.9 \\
\hline Total $\left(\sum=4,640\right)$ & 3,103 & 66.9 & 769 & 16.6 & 422 & 9.1 & 346 & 7.5 \\
\hline \multicolumn{9}{|c|}{2007 (sub-sample) } \\
\hline \multicolumn{9}{|l|}{ South } \\
\hline Urban & 369 & 11.2 & 42 & 1.3 & 193 & 5.8 & 55 & 1.7 \\
\hline Rural & 520 & 15.7 & 1 & 0.0 & 96 & 2.9 & 16 & 0.5 \\
\hline \multicolumn{9}{|l|}{ North } \\
\hline Urban & 729 & 22.1 & 323 & 9.8 & 19 & 0.6 & 115 & 3.5 \\
\hline Rural & 654 & 19.8 & 101 & 3.1 & 8 & 0.2 & 63 & 1.9 \\
\hline Total $\left(\sum=3,304\right)$ & 2,272 & 68.8 & 467 & 14.1 & 316 & 9.6 & 249 & 7.5 \\
\hline \multicolumn{9}{|c|}{2009 (sub-sample) } \\
\hline \multicolumn{9}{|l|}{ South } \\
\hline Urban & 269 & 9.9 & 35 & 1.3 & 167 & 6.1 & 41 & 1.5 \\
\hline Rural & 448 & 16.5 & 1 & 0.0 & 90 & 3.3 & 16 & 0.6 \\
\hline \multicolumn{9}{|l|}{ North } \\
\hline Urban & 595 & 21.9 & 252 & 9.3 & 17 & 0.6 & 85 & 3.1 \\
\hline Rural & 566 & 20.8 & 80 & 2.9 & 5 & 0.2 & 56 & 2.1 \\
\hline Total $\left(\sum=2,723\right)$ & 1,878 & 69.0 & 368 & 13.5 & 279 & 10.2 & 198 & 7.3 \\
\hline
\end{tabular}

Source: Authors' illustration based on KIHS data. 
Table 2: Descriptive statistics for welfare measures

Full sample

\begin{tabular}{|c|c|c|c|c|c|c|c|c|c|}
\hline & \multirow{2}{*}{ Mean } & \multirow{2}{*}{$S D$} & \multirow{2}{*}{ Median } & \multirow{2}{*}{ Min } & \multirow{2}{*}{$\operatorname{Max}$} & \multicolumn{3}{|c|}{ Correlation } & \multirow{2}{*}{$\begin{array}{l}\text { \# of } \\
\text { obs. }\end{array}$} \\
\hline & & & & & & $P C E$ & $A I$ & $H V$ & \\
\hline \multicolumn{10}{|c|}{2005} \\
\hline $\begin{array}{l}\text { Per capita } \\
\text { expenditure (PCE) } \\
\text { per day, Soms }\end{array}$ & 37.1 & 19.0 & 31.8 & 6.7 & 107.8 & 1 & & & 4,640 \\
\hline $\begin{array}{l}\text { Asset index (AI), } \\
\text { standardised }\end{array}$ & 2.60 & 0.98 & 2.41 & 1.00 & 6.37 & $0.4178 *$ & 1 & & 4,629 \\
\hline $\begin{array}{l}\text { House value (HV), } \\
\text { '000 Soms }\end{array}$ & 230.0 & 236.1 & 150.0 & 1.0 & $1,100.0$ & $0.2569 *$ & $0.4450 *$ & 1 & 3,646 \\
\hline \multicolumn{10}{|c|}{2007 sub-sample } \\
\hline $\begin{array}{l}\text { Per capita } \\
\text { expenditure (PCE) } \\
\text { per day, Soms }\end{array}$ & 49.5 & 25.5 & 42.4 & 12.3 & 150.6 & 1 & & & 3,304 \\
\hline $\begin{array}{l}\text { Asset index (AI), } \\
\text { standardised }\end{array}$ & 2.73 & 0.97 & 2.58 & 1.00 & 6.27 & $0.4205^{*}$ & 1 & & 3,297 \\
\hline $\begin{array}{l}\text { House value (HV), } \\
\text { '000 Soms }\end{array}$ & 452.8 & 508.5 & 293.0 & 2.0 & $4,394.5$ & $0.3077^{*}$ & $0.4039 *$ & 1 & 2,753 \\
\hline \multicolumn{10}{|c|}{2009 sub-sample } \\
\hline $\begin{array}{l}\text { Per capita } \\
\text { expenditure (PCE) } \\
\text { per day, Soms }\end{array}$ & 74.4 & 34.0 & 65.9 & 14.1 & 203.6 & 1 & & & 2,723 \\
\hline $\begin{array}{l}\text { Asset index (AI), } \\
\text { standardised }\end{array}$ & 2.85 & 0.98 & 2.73 & 1.00 & 6.04 & $0.3587^{*}$ & 1 & & 2,707 \\
\hline $\begin{array}{l}\text { House value (HV), } \\
\text { '000 Soms }\end{array}$ & 549.0 & 503.2 & 378.1 & 6.8 & 3,828.0 & $0.2134 *$ & $0.3737 *$ & 1 & 2,344 \\
\hline
\end{tabular}

Note: No survey settings are taken into account here. The expenditure and house value data are in 2005 prices. *- significant at 1 percent level.

Source: Authors' calculation based on KIHS data. 
Table 3: Definition of explanatory variables

\begin{tabular}{|c|c|}
\hline Variables & Definition \\
\hline Pre-school children & Number of children in the pre-school age (0-6 years) in the household \\
\hline School children & Number of children in the school age (7-17 years) in the household \\
\hline Adults & Number of working-age adults in the household \\
\hline Elderly & $\begin{array}{l}\text { Number of elderly people in the household, defined according to official pension } \\
\text { age, which changed over time }\end{array}$ \\
\hline Age of head & Age of a household head \\
\hline Female head & Dummy variable, taking the value 1 if household head is female, 0 otherwise \\
\hline Schooling years & $\begin{array}{l}\text { Average number of years of education of all household members older than } 18 \\
\text { years }\end{array}$ \\
\hline Hours in services & $\begin{array}{l}\text { Hours of work per week in the services sector (comprising of trade, transport and } \\
\text { communication, real estate, hotels and dining, financial services) by a } \\
\text { representative employed household member }\end{array}$ \\
\hline Irrigated land size & Area of irrigated and cultivated land in hectares \\
\hline Sheep equivalent units & Sheep equivalent units (one cattle is equal to five sheep) \\
\hline Rural & $\begin{array}{l}\text { Dummy variable, taking the value } 1 \text { if household resides in a rural area, } 0 \\
\text { otherwise }\end{array}$ \\
\hline Djalalabad & $\begin{array}{l}\text { Dummy variable, taking the value } 1 \text { if household resides in Djalalabad oblast, } 0 \\
\text { otherwise }\end{array}$ \\
\hline Batken & $\begin{array}{l}\text { Dummy variable, taking the value } 1 \text { if household resides in Batken oblast, } 0 \\
\text { otherwise }\end{array}$ \\
\hline Osh & $\begin{array}{l}\text { Dummy variable, taking the value } 1 \text { if household resides in Osh oblast, } 0 \\
\text { otherwise }\end{array}$ \\
\hline
\end{tabular}


Table 4: Household characteristics

South sample only

\begin{tabular}{|c|c|c|c|c|c|c|c|c|c|}
\hline & \multicolumn{3}{|c|}{2005} & \multicolumn{3}{|c|}{2007} & \multicolumn{3}{|c|}{2009} \\
\hline & All & Kyrgyz & Uzbek & All & Kyrgyz & Uzbek & All & Kyrgyz & Uzbek \\
\hline Pre-school children & 0.56 & 0.60 & 0.56 & 0.50 & 0.53 & 0.54 & 0.43 & 0.46 & 0.46 \\
\hline School children & 1.40 & 1.48 & 1.48 & 1.35 & 1.43 & 1.31 & 1.27 & 1.37 & $1.19 *$ \\
\hline Adults & 2.23 & 2.23 & $2.51 *$ & 2.20 & 2.19 & $2.50 *$ & 2.30 & 2.31 & 2.49 \\
\hline Elderly & 0.34 & 0.28 & $0.38 *$ & 0.32 & 0.26 & $0.40 *$ & 0.36 & 0.30 & $0.44 *$ \\
\hline Age of head & 48.89 & 47.14 & $50.67 *$ & 50.13 & 48.62 & $52.55^{*}$ & 52.19 & 51.05 & $53.66^{*}$ \\
\hline Female head & 0.32 & 0.29 & 0.32 & 0.35 & 0.33 & 0.34 & 0.35 & 0.33 & 0.35 \\
\hline Schooling years & 10.82 & 11.04 & $10.02 *$ & 10.81 & 11.02 & $10.06^{*}$ & 10.70 & 10.88 & $10.10^{*}$ \\
\hline Hours/week worked in services & 12.42 & 11.36 & $17.38^{*}$ & 12.81 & 11.53 & 18.74 & 13.19 & 11.55 & $18.81^{*}$ \\
\hline Irrigated land size & 3.06 & 3.97 & $1.43 *$ & 4.14 & 5.35 & $1.68 *$ & 3.96 & 5.22 & $1.55^{*}$ \\
\hline Sheep equivalent units & 7.33 & 9.56 & $3.03 *$ & 8.29 & 10.91 & $2.87 *$ & 8.39 & 11.31 & $2.60 *$ \\
\hline Rural & 0.41 & 0.51 & $0.27 *$ & 0.49 & 0.58 & $0.33 *$ & 0.52 & 0.62 & $0.35 *$ \\
\hline Djalalabad & 0.37 & 0.38 & 0.37 & 0.37 & 0.37 & 0.38 & 0.35 & 0.35 & 0.36 \\
\hline Batken & 0.28 & 0.30 & $0.16^{*}$ & 0.28 & 0.30 & $0.15 *$ & 0.29 & 0.33 & $0.16^{*}$ \\
\hline Osh & 0.35 & 0.32 & 0.48 & 0.35 & 0.32 & 0.46 & 0.36 & 0.32 & 0.49 \\
\hline Observations & 1,732 & 1,167 & 383 & 1,292 & 889 & 289 & 1,067 & 717 & 257 \\
\hline
\end{tabular}

Note: Cell entries are survey means. No sampling weights are taken into account. * indicates that the difference in the means between Kyrgyz and Uzbeks is statistically significant at the $5 \%$ level.

Source: Authors' calculation based on KIHS data. 
Table 5: OLS regression results for welfare functions

South sample only; pooled data for the years 2005, 2007, and 2009

\begin{tabular}{|c|c|c|c|c|c|c|}
\hline & \multicolumn{2}{|c|}{ (1) Per capita expenditure (log) } & \multicolumn{2}{|c|}{ (2) Asset index (log) } & \multicolumn{2}{|c|}{ (3) House value (log) } \\
\hline & Kyrgyz & Uzbek & Kyrgyz & Uzbek & Kyrgyz & Uzbek \\
\hline Preschool children & $\begin{array}{c}-.188 \\
(-16.31)^{* * *}\end{array}$ & $\begin{array}{c}-.129 \\
(-10.20)^{* * *}\end{array}$ & $\begin{array}{l}-.00264 \\
(-0.22)\end{array}$ & $\begin{array}{c}-.0268 \\
(-1.84)^{*}\end{array}$ & $\begin{array}{c}-.0436 \\
(-1.77)^{*}\end{array}$ & $\begin{array}{l}.00982 \\
(0.35)\end{array}$ \\
\hline School age children & $\begin{array}{c}-.155 \\
(-20.16)^{* * *}\end{array}$ & $\begin{array}{c}-.155 \\
(-8.60) * * *\end{array}$ & $\begin{array}{c}.0171 \\
(-3.16)^{* * *}\end{array}$ & $\begin{array}{c}-.0236 \\
(-3.04) * * *\end{array}$ & $\begin{array}{l}.00547 \\
(0.39)\end{array}$ & $\begin{array}{l}.0443 \\
(1.22) \\
\end{array}$ \\
\hline Adults & $\begin{array}{c}-.1 \\
(-10.81)^{* * *}\end{array}$ & $\begin{array}{c}-.0959 \\
(-7.42)^{* * *}\end{array}$ & $\begin{array}{l}.0115 \\
(1.25) \\
\end{array}$ & $\begin{array}{l}.0103 \\
(1.00) \\
\end{array}$ & $\begin{array}{c}.0671 \\
(3.01)^{* * *}\end{array}$ & $\begin{array}{l}.0294 \\
(1.20) \\
\end{array}$ \\
\hline Elderly & $\begin{array}{c}-.141 \\
(-6.33)^{* * *}\end{array}$ & $\begin{array}{c}-.118 \\
(-4.40)^{* * *} \\
\end{array}$ & $\begin{array}{c}.0371 \\
(1.73)^{*} \\
\end{array}$ & $\begin{array}{c}-.00153 \\
(-0.05) \\
\end{array}$ & $\begin{array}{l}.0708 \\
(1.05) \\
\end{array}$ & $\begin{array}{l}-.0371 \\
(-0.51) \\
\end{array}$ \\
\hline Age of HH head & $\begin{array}{c}.00204 \\
(2.18)^{* *} \\
\end{array}$ & $\begin{array}{c}.000182 \\
(0.12) \\
\end{array}$ & $\begin{array}{c}.00281 \\
(2.71)^{* * *}\end{array}$ & $\begin{array}{c}.00368 \\
(2.26)^{* *}\end{array}$ & $\begin{array}{l}.00197 \\
(0.77)\end{array}$ & $\begin{array}{l}.00439 \\
(1.30)\end{array}$ \\
\hline Female HH head & $\begin{array}{l}-.0287 \\
(-1.50)\end{array}$ & $\begin{array}{c}-.0528 \\
(-1.79)^{*}\end{array}$ & $\begin{array}{c}-.0359 \\
(-2.38)^{* *}\end{array}$ & $\begin{array}{l}-.0342 \\
(-1.10)\end{array}$ & $\begin{array}{l}-.0582 \\
(-1.38)\end{array}$ & $\begin{array}{l}-.0871 \\
(-1.32)\end{array}$ \\
\hline Average years of schooling of adults & $\begin{array}{c}.0286 \\
(6.13)^{* * *}\end{array}$ & $\begin{array}{c}.0223 \\
(4.53)^{* * *} \\
\end{array}$ & $\begin{array}{c}.0515 \\
(9.30)^{* * * *}\end{array}$ & $\begin{array}{c}.0588 \\
(6.49)^{* * *}\end{array}$ & $\begin{array}{c}.0706 \\
(3.91) * * *\end{array}$ & $\begin{array}{c}.02 \\
(2.23)^{* *}\end{array}$ \\
\hline Hours/week worked in services & $\begin{array}{c}.00169 \\
(3.32)^{* * *} \\
\end{array}$ & $\begin{array}{c}.00213 \\
(2.53)^{* *} \\
\end{array}$ & $\begin{array}{c}.00194 \\
(3.33)^{* * *}\end{array}$ & $\begin{array}{c}.00145 \\
(3.19)^{* * *}\end{array}$ & $\begin{array}{c}.00148 \\
(0.79) \\
\end{array}$ & $\begin{array}{c}.00294 \\
(1.54) \\
\end{array}$ \\
\hline Area of cultivated and irrigated land & $\begin{array}{c}.000807 \\
(0.96) \\
\end{array}$ & $\begin{array}{c}-.00446 \\
(-0.81)\end{array}$ & $\begin{array}{l}.0013 \\
(1.63) \\
\end{array}$ & $\begin{array}{c}-.013 \\
(-2.37)^{* *}\end{array}$ & $\begin{array}{l}.0036 \\
(1.32) \\
\end{array}$ & $\begin{array}{l}-.0194 \\
(-1.14)\end{array}$ \\
\hline Sheep equivalent unit & $\begin{array}{c}.00469 \\
(5.21)^{* * *}\end{array}$ & $\begin{array}{c}.0072 \\
(4.45)^{* * *}\end{array}$ & $\begin{array}{c}.00165 \\
(3.03)^{* * *}\end{array}$ & $\begin{array}{c}-.000062 \\
(-0.02)\end{array}$ & $\begin{array}{l}.00135 \\
(0.85) \\
\end{array}$ & $\begin{array}{l}.00278 \\
(0.56) \\
\end{array}$ \\
\hline Rural & $\begin{array}{c}-.097 \\
(-2.94)^{* * *}\end{array}$ & $\begin{array}{c}-.00361 \\
(-0.10)\end{array}$ & $\begin{array}{c}-.371 \\
(-6.08)^{* * *}\end{array}$ & $\begin{array}{c}-.131 \\
(-2.20)^{* *}\end{array}$ & $\begin{array}{l}-.0558 \\
(-0.34)\end{array}$ & $\begin{array}{l}.0465 \\
(0.26)\end{array}$ \\
\hline Djalalabad & $\begin{array}{c}-.189 \\
(-5.40)^{* * *}\end{array}$ & $\begin{array}{c}-.0749 \\
(-2.18)^{* *}\end{array}$ & $\begin{array}{l}.0651 \\
(0.77) \\
\end{array}$ & $\begin{array}{c}-.022 \\
(-0.33)\end{array}$ & $\begin{array}{c}-.431 \\
(-1.83)^{*}\end{array}$ & $\begin{array}{c}-.548 \\
(-2.16)^{* *}\end{array}$ \\
\hline Batken & $\begin{array}{l}-.0146 \\
(-0.38)\end{array}$ & $\begin{array}{c}-.087 \\
(-1.29)\end{array}$ & $\begin{array}{l}-.0109 \\
(-0.15)\end{array}$ & $\begin{array}{c}-.191 \\
(-1.66)\end{array}$ & $\begin{array}{c}-.149 \\
(-1.05)\end{array}$ & $\begin{array}{c}-.468 \\
(-2.54)^{* *}\end{array}$ \\
\hline R-squared & 0.660 & 0.667 & 0.420 & 0.307 & 0.231 & 0.264 \\
\hline Observations & 2,766 & 929 & 2,755 & 925 & 2,370 & 831 \\
\hline
\end{tabular}

Note: Cell entries are coefficients, t-values are in brackets. *** -significant at $1 \%$ level, $* *$ - at $5 \%$ level, * - at $10 \%$ level. Calculation of standard errors takes clustering at the community level into account. Year dummies and a constant are included. Osh is the reference for oblasts.

Source: Authors' calculation based on KIHS data. 
Table 6: Oaxaca-Blinder decomposition of welfare differences between Kyrgyz and Uzbeks

South sample only

\begin{tabular}{|c|c|c|c|c|c|c|}
\hline & $\begin{array}{c}\text { Difference in mean } \\
\text { (Kyrgyz minus Uzbeks) }\end{array}$ & Characteristics effect & Share of total difference & Coefficients effect & Share of total difference & Number of observations \\
\hline \multicolumn{7}{|c|}{ (Log) Per capita expenditure } \\
\hline 2005 & $\begin{array}{c}0.0529 \\
(1.41) \\
\end{array}$ & $\begin{array}{c}0.0459 \\
(1.51)\end{array}$ & 86.8 & $\begin{array}{c}0.0070 \\
(0.21)\end{array}$ & 13.2 & 1,550 \\
\hline 2007 & $\begin{array}{c}0.0855^{* * *} \\
(2.73) \\
\end{array}$ & $\begin{array}{c}0.0692^{* *} \\
(2.33) \\
\end{array}$ & 80.9 & $\begin{array}{c}0.0163 \\
(0.56) \\
\end{array}$ & 19.1 & 1,178 \\
\hline 2009 & $\begin{array}{c}0.0200 \\
(0.52) \\
\end{array}$ & $\begin{array}{c}0.0279 \\
(.85) \\
\end{array}$ & 139.6 & $\begin{array}{c}-0.0079 \\
(-0.22)\end{array}$ & -39.6 & 974 \\
\hline \multicolumn{7}{|c|}{ (Log) Asset index } \\
\hline 2005 & $\begin{array}{c}-0.0967 * * \\
(-2.23) \\
\end{array}$ & $\begin{array}{l}-.0497 \\
(-1.29) \\
\end{array}$ & 51.4 & $\begin{array}{l}-.0470 \\
(-1.36) \\
\end{array}$ & 48.6 & 1,545 \\
\hline 2007 & $\begin{array}{c}-0.0626 \\
(-1.40) \\
\end{array}$ & $\begin{array}{c}-0.0525 \\
(-1.43) \\
\end{array}$ & 83.9 & $\begin{array}{c}-0.0101 \\
(-0.25) \\
\end{array}$ & 16.1 & 1,173 \\
\hline 2009 & $\begin{array}{c}-0.0899 * * \\
(-2.03) \\
\end{array}$ & $\begin{array}{c}-0.0777^{*} \\
(-1.81)\end{array}$ & 86.4 & $\begin{array}{c}-0.0121 \\
(-0.32) \\
\end{array}$ & 13.6 & 968 \\
\hline \multicolumn{7}{|c|}{ (Log) House value } \\
\hline 2005 & $\begin{array}{c}-0.4934 * * * \\
(-3.11) \\
\end{array}$ & $\begin{array}{l}-0.0707 \\
(-0.60) \\
\end{array}$ & 14.3 & $\begin{array}{c}-0.4227^{* * * *} \\
(-3.06)\end{array}$ & 85.7 & 1,221 \\
\hline 2007 & $\begin{array}{c}-0.458 * * * \\
(-3.88)\end{array}$ & $\begin{array}{c}-0.0165 \\
(-0.19) \\
\end{array}$ & 3.60 & $\begin{array}{c}-0.4415^{* * * *} \\
(-3.67)\end{array}$ & 96.4 & 1,077 \\
\hline 2009 & $\begin{array}{c}-0.4461 * * * \\
(-5.25)\end{array}$ & $\begin{array}{c}0.0266 \\
(0.68) \\
\end{array}$ & -6.0 & $\begin{array}{c}-0.4727 * * * \\
(-5.45)\end{array}$ & 106.0 & 907 \\
\hline
\end{tabular}

Note: *** - difference in the means is significant at $1 \%$ level, ** - at $5 \%$ level, * - at $10 \%$ level.

Source: Authors' calculation based on KIHS data. 
Table 7: Sensitivity checks: Oaxaca-Blinder decomposition

\begin{tabular}{|c|c|c|c|c|c|c|}
\hline & (1) Basic & (2) Urban only & (3) Rural only & (4) With weights & (5) Incl. North & (6) 2009 sub-sample \\
\hline \multicolumn{7}{|c|}{ Per capita expenditure (log) } \\
\hline \multicolumn{7}{|l|}{2005} \\
\hline Difference in mean & 0.0529 & $0.1344 * * *$ & 0.0074 & 0.0445 & $0.0736 * *$ & 0.0170 \\
\hline Characteristics effect (share) & 86.76 & $75.75^{* * *}$ & $1502.82 * * *$ & 187.99 & $123.93 * * *$ & 109.20 \\
\hline Coefficients effect (share) & 13.24 & 24.25 & $-1402.82 * *$ & -87.99 & -23.93 & -9.20 \\
\hline \multicolumn{7}{|l|}{2007} \\
\hline Difference in mean & $0.0855 * * *$ & $0.1192 * *$ & $0.1058 * *$ & 0.0450 & $0.1145^{* * *}$ & $0.0634^{*}$ \\
\hline Coefficients effect (share) & 19.06 & 49.86 & -41.05 & $-175.06^{*}$ & 0.94 & 28.80 \\
\hline \multicolumn{7}{|l|}{2009} \\
\hline Difference in mean & 0.0200 & $0.0974 * *$ & 0.0162 & -0.0313 & -0.0257 & 0.0200 \\
\hline Characteristics effect (share) & 139.64 & $77.05^{* *}$ & $488.43 *$ & -255.21 & -4.59 & 139.64 \\
\hline Coefficients effect (share) & -39.64 & 22.95 & -388.43 & $355.21^{*}$ & 104.59 & -39.64 \\
\hline \multicolumn{7}{|c|}{ Asset index (log) } \\
\hline \multicolumn{7}{|l|}{2005} \\
\hline Coefficients effect (share) & 48.60 & 60.58 & $105.12^{* * *}$ & $93.44^{* * *}$ & $174.41^{* *}$ & 36.79 \\
\hline \multicolumn{7}{|l|}{2007} \\
\hline Difference in mean & -0.0626 & $0.1033 * *$ & $-0.1045 * *$ & -0.0705 & -0.0038 & $-0.0800 *$ \\
\hline Characteristics effect (share) & 83.87 & 18.00 & 2.36 & -4.67 & -997.23 & $90.10^{*}$ \\
\hline Coefficients effect (share) & 16.13 & $82.00 * *$ & $97.64 *$ & 104.67 & 1097.23 & 9.90 \\
\hline \multicolumn{7}{|l|}{2009} \\
\hline Difference in mean & $-0.0899 * *$ & $0.1116^{* *}$ & $-0.1242 * *$ & -0.0635 & -0.0206 & $-0.0899 * *$ \\
\hline Characteristics effect (share) & $86.43 *$ & 10.17 & 9.29 & 65.66 & -124.02 & $86.43 *$ \\
\hline Coefficients effect (share) & 13.57 & $89.83^{* *}$ & $90.71^{*}$ & 34.34 & 224.02 & 13.57 \\
\hline
\end{tabular}

Note: *** - difference in the means is significant at $1 \%$ level, ** - at $5 \%$ level, * - at $10 \%$ level.

Source: Authors' calculation based on KIHS data. 
Table 7: Sensitivity checks: Oaxaca-Blinder decomposition (ctd.)

\begin{tabular}{|c|c|c|c|c|c|c|}
\hline & (1) Basic & (2) Urban only & (3) Rural only & (4) With weights & (5) Incl. North & (6) 2009 sub-sample \\
\hline \multicolumn{7}{|c|}{ House value (log) } \\
\hline \multicolumn{7}{|l|}{2005} \\
\hline Difference in mean & $-0.4934 * * *$ & $-0.6265^{* * *}$ & $-0.1577 * * *$ & $-0.4638 * * *$ & $-0.5578^{* * *}$ & $-0.5647 * * *$ \\
\hline Characteristics effect (share) & 14.33 & 37.07 & -5.12 & -11.18 & 31.89 & 2.57 \\
\hline Coefficients effect (share) & $85.67 * * *$ & $62.93 * *$ & $105.12 * * *$ & $111.18^{* * *}$ & $68.11^{* * *}$ & $97.43^{* * *}$ \\
\hline \multicolumn{7}{|l|}{2007} \\
\hline Difference in mean & $-0.4580 * * *$ & $-0.5161 * * *$ & $-0.3570^{*}$ & $-0.5791 * * *$ & $-0.5055^{* * *}$ & $-0.4932 * * *$ \\
\hline Coefficients effect (share) & $96.40 * * *$ & $73.68 * * *$ & $125.67 * * *$ & $95.58 * * *$ & $72.14 * * *$ & $96.68 * * *$ \\
\hline \multicolumn{7}{|l|}{2009} \\
\hline Difference in mean & $-0.4461 * * *$ & $-0.3395 * * *$ & $-0.5386 * * *$ & $-0.6060 * * *$ & $-0.4871 * * *$ & $-0.4461 * * *$ \\
\hline Characteristics effect (share) & -5.96 & -19.41 & -14.63 & 2.09 & $29.30 * *$ & -5.96 \\
\hline Coefficients effect (share) & $105.96 * * *$ & $119.41^{* * *}$ & $114.63^{* * *}$ & $97.91 * * *$ & $70.70 * * *$ & $105.96 * * *$ \\
\hline
\end{tabular}

effect (share)

$119.41 * * *$

$114.63 * * *$

$97.91 * * *$

$70.70 * * *$

$105.96 * * *$

Note: $* * *$ - difference in the means is significant at $1 \%$ level, ** - at $5 \%$ level, * - at $10 \%$ level.

Source: Authors' calculation based on KIHS data.

Table 8: Dwelling characteristics of Kyrgz and Uzbeks, 2005

South sample only

\begin{tabular}{|l|r|r|r|r|r|r|}
\hline & \multicolumn{2}{|c|}{ Rural and urban } & \multicolumn{2}{c|}{ Rural } & \multicolumn{2}{c|}{ Urban } \\
\hline & \multicolumn{1}{|c|}{ Kyrgyz } & Uzbek & \multicolumn{1}{c|}{ Kyrgyz } & Uzbek & Kyrgyz & Uzbek \\
\hline $\begin{array}{l}\text { Area of } \\
\text { dwelling }\left(\mathrm{m}^{2}\right)\end{array}$ & 82.01 & 85.31 & 98.20 & 97.62 & 65.29 & $80.72^{*}$ \\
\hline $\begin{array}{l}\text { Living area of } \\
\text { dwelling (m }\end{array}$ & 58.97 & 62.11 & 72.07 & 75.29 & 45.43 & $57.19^{2}$ \\
\hline $\begin{array}{l}\text { Number of } \\
\text { rooms }\end{array}$ & 3.37 & $3.77^{*}$ & 3.87 & 4.06 & 2.85 & $3.66^{*}$ \\
\hline $\begin{array}{l}\text { Per capita area } \\
\text { of dwelling }\left(\mathrm{m}^{2}\right)\end{array}$ & 20.47 & 20.46 & 22.40 & 22.78 & 18.48 & 19.59 \\
\hline
\end{tabular}

Note: Cell entries are survey means. No sampling weights are taken into account. * indicates that the mean of the Uzbek

group is different from the mean of the Kyrgyz group at a significance level of 5 percent.

Source: Authors' calculation based on KIHS data. 